\title{
Appendiceal Carcinoid pNX TNM Finding v7
}

National Cancer Institute

\section{Source}

National Cancer Institute. Appendiceal Carcinoid pNX TNM Finding v7. NCI Thesaurus. Code C89932.

Appendiceal carcinoid in which regional lymph nodes cannot be assessed. (from AJCC 7th Ed.) 